\title{
Determination of Carteolol in Pure and Pharmaceutical Formulation by Spectrophotometric Method
}

\author{
Malek Okdeh*, Chahid Moustpha and Mohammad Shraitah
}

Department of Chemistry, Faculty of Science, Teshreen University, Lattakia, Syria

\begin{abstract}
An accurate, simple, fast, and good sensitive Spectrophotometric method have been developed for the determination of Carteolol based on the formation of complex (ion-pair complexes) between the Carteolol (CRT) and Alizarin yellow $\mathrm{R}$ Sodium salt $(\mathrm{AR})$ at $\mathrm{pH}=11.20$. This reaction produces a complex red color which is absorbed maximally at $500 \mathrm{~nm}$. Beer's law was obeyed in the range of $1.80-197.30 \mathrm{ug} / \mathrm{mL}$ with molar absorptivity of $1.7663 \times 10^{3}$ $\mathrm{L}$ mole $^{-1} \mathrm{~cm}^{-1}$. The effects of analytical parameters on the reported system were investigated. The results were validated statistically. The proposed method was applied to commercially available tablets. Interferences of the other ingredients and excipients were not observed.
\end{abstract}

Keywords: Carteolol; Complex formation; Spectrophotometry

\section{Introduction}

Carteolol is a nonselective beta-adrenergic blocking agent with associated intrinsic sympathomimetic activity and without significant membrane-stabilizing activity. Carteolol hydrochloride reduces normal and elevated intraocular pressure (IOP) whether accompanied by glaucoma or not the correct mechanism of the ocular hypotensive effect of beta-blockers has not been definitely demonstrated. In general, beta-adrenergic blockers reduce cardiac output in patients in good, poor and very cardiovascular health. In different patients with severe impairment of myocardial function and $\beta$ - blockers may inhibit the sympathetic stimulation necessary to maintain adequate cardiac function. $\beta$ - adrenergic blockers may also increase airway resistance in the bronchi and bronchioles due to unopposed parasympathetic activity [1-3]. Chemically Carteolol Hydrochloride is 5-[(2RS)-3-[(1, 1-Dimethylethyl) amino]-2-hydroxypropoxy]-3, 4- dihydroquinolin$2(1 \mathrm{H})$ - one hydrochloride. It has the molecular formula $\mathrm{C}_{16} \mathrm{H}_{25} \mathrm{~N}_{2} \mathrm{O}_{3} \mathrm{Cl}$ and the molecular weight is 328.8. Carteolol Hydrochloride is a white, crystalline powder. Carteolol hydrochloride is soluble in water, slightly soluble in alcohol, sparingly soluble in methanol and is practically insoluble in methylene chloride $[4,5]$. for the simultaneous quantification of carteolol and dorzolamide in rabbit aqueous humor $(\mathrm{AH})$ and ciliary body $(\mathrm{CB})$ has been developed and validated using reversed phase-high performance liquid chromatography (RP-HPLC) with isocratic elution coupled with atmospheric pressure chemical ionization mass spectrometry/mass spectrometry (APCI-MS/MS) $[6,7]$.

\section{Experimental}

\section{Materials and methods}

All the reagents and chemicals used were of Analytical Reagent Grade. Carteolol Hydrochloride was kindly supplied by GSK Pvt. Ltd. Mumbai, India. Spectral and absorbance measurements were made with UV-Vis Spectrophotometer (OpTMA SP3000 from Korea) double beam spectrophotometer with $1 \mathrm{~cm}$ matched quartz cell.

\section{Reagents and solutions}

Stjjock standard solution of Carteolol $\left(1 \times 10^{-3} \mathrm{M}\right)$ was prepared by dissolving $32.88 \mathrm{mg}$ of Carteolol in $100 \mathrm{~mL}$ of $\mathrm{NaOH}(0.03 \mathrm{~N})$ in 100 $\mathrm{ml}$ volumetric flask. The standard solution was prepared by dilution of the stock standard solution with $\mathrm{NaOH}(0.03 \mathrm{~N})$ to reach concentration $\left(1 \times 10^{-4} \mathrm{M}\right)$ of CRT. This solution was stored in a well closed vessel. The solution is stable. Solutions of reagent Alizarin yellow R Sodium salt
(AR) were prepared with a concentration of $\left(1 \times 10^{-3} \mathrm{M}\right)$ by dissolving suitable weight of the reagent in $\mathrm{NaOH}(0.03 \mathrm{~N})$ and diluted to the mark in $100 \mathrm{ml}$ volumetric flask.

Buffer solution( $\mathrm{PH}=2.0-12.0$ ): different buffer solution was used $0.1 \mathrm{M}$ Citrate buffer, $0.1 \mathrm{M}$ Ammonium buffer, $0.1 \mathrm{M}$ borate buffer and $0.1 \mathrm{M}$ britton buffer solution.

\section{Proposed procedure}

To different aliquots of Carteolol $(1.80-197.30 \mu \mathrm{g} / \mathrm{mL})$ in tubes, add $61.84 \mu \mathrm{g} / \mathrm{ml}$ of Alizarin yellow R Sodium salt (AR) solution and added $1 \mathrm{ml}$ from Britton buffer at $\mathrm{pH} 11.2$. Transfer to $10 \mathrm{~mL}$ volumetric flask. Make the volume up to the mark with $\mathrm{NaOH}(0.03 \mathrm{~N})$. Measure the absorbance of the solution at $500 \mathrm{~nm}$ against reagent blank.

\section{Results and Discussion}

Preliminary investigations have shown that Carteolol reacts with Alizarin yellow R Sodium salt (AR) in Britton buffer $\mathrm{pH}=11.20$ to give the color complex, which is absorbed at a maximum of $500 \mathrm{~nm}$ as shown in Figure 1.

To optimize the reaction conditions, different parameters have been investigated such as reagent concentration, color stability, $\mathrm{pH}$ buffer and amount of buffer $(\mathrm{pH}=11.20)$.

\section{Effect of time on the stability of the color CRT-AR complex}

Developed color was stable up to 2 hours which was considered sufficient time for an analyst to carry out analysis (Figure 2).

\section{Effect of pH buffer}

The effect of $\mathrm{pH}$ was studied in the presence of various buffers such as Briton, Citrate, borate and Ammonium. It was observed that

*Corresponding author: Malek Okdeh, Department of Chemistry, Faculty of Science, Teshreen University, Lattakia, Syria, Tel: 96341352451; E-mail: dr.malekokdeh@yahoo.com

Received January 18, 2016; Accepted February 11, 2016; Published February 15,2016

Citation: Okdeh M, Moustpha C, Shraitah M (2016) Determination of Carteolol in Pure and Pharmaceutical Formulation by Spectrophotometric Method. Med chem (Los Angeles) 6: 115-118. doi:10.4172/2161-0444.1000334

Copyright: $\odot 2016$ Okdeh M, et al. This is an open-access article distributed under the terms of the Creative Commons Attribution License, which permits unrestricted use, distribution, and reproduction in any medium, provided the original author and source are credited. 


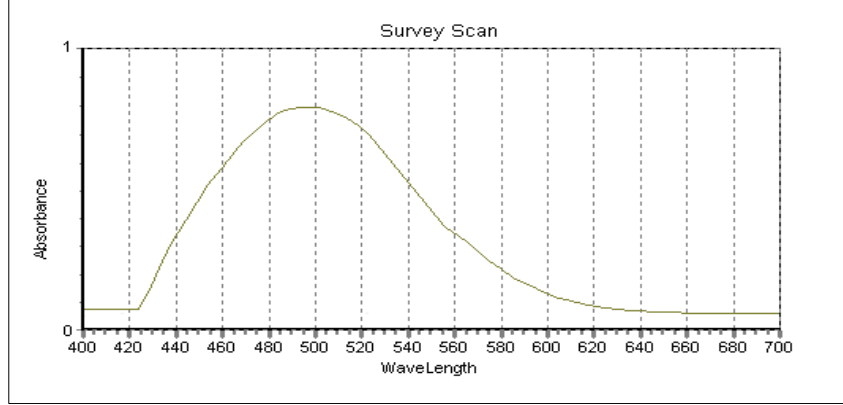

Figure 1: Absorption spectrum of CRT-AR Formation.

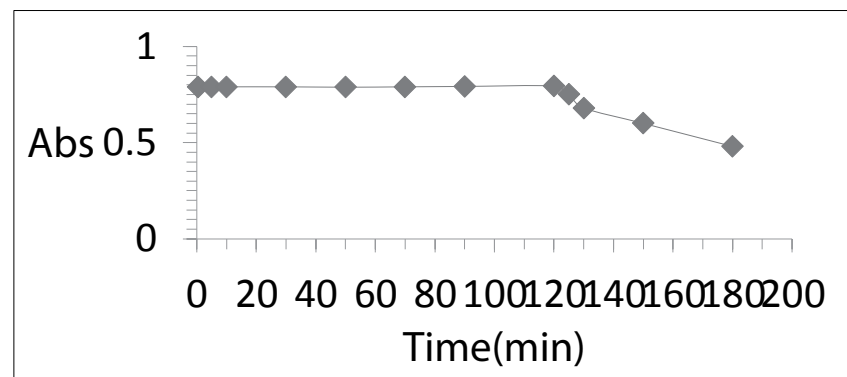

Figure 2: Effect of time on the color Development.

the maximum color intensity and constant absorbance were found in britton buffer solution $(0.1 \mathrm{M})$ of $\mathrm{pH}=11.20$ for CRT-AR system using 1 $\mathrm{ml}$ of britton buffer solution $(0.1 \mathrm{M})$ as shown in Figure 3 .

\section{Effect of amount of britton $(0.1 \mathrm{M})$ buffer $(\mathrm{pH}=11.20)$}

The optimum of amount of britton buffer solution $(0.1 \mathrm{M})$ for the assay of drugs was studied. $1 \mathrm{ml}$ of britton buffer solution $(0.1 \mathrm{M}) \mathrm{pH}=$ 11.20 sufficient for complete color development for CRT-AR complex as shown in Figure 4.

\section{Effect of reagent concentration}

The effect of Alizarin yellow R Sodium salt (AR) concentration on the color development was investigated. $2.0 \mathrm{~mL}$ of Alizarin yellow R Sodium salt $\left(10^{-3} \mathrm{M}\right)$ reagent produced maximum color intensity (Figure 5).

\section{Molar Ratios Determination of CRT-AR complex}

The molar ratio was determined using the molar ratio methods [8] and continuous variation [9] methods. The ratio were found to be 1:3 for CRT:AR (Figures 6 and 7).

\section{Linearity and sensitivity}

A linear relation was obtained between absorbance and concentration of CRT in the range of $1.80-197.30 \mu \mathrm{g} / \mathrm{mL}$ (Figure 8). The graphs show negligible intercept and they are described by the regression equation, $A=m C+b$ (where $A$ is the absorbance of $1 \mathrm{~cm}$ layer, $\mathrm{m}$ is the slope, $\mathrm{b}$ is the intercept and $\mathrm{C}$ is the concentration of the measured solution in $\mu \mathrm{g} . \mathrm{ml}-1$ ) obtained by the least-squares method [10]. The high molar absorptivity of the resulting colored complex indicate the good sensitivity of the method. The Beer's law limits, Sandell sensitivity, molar absorptivity, linear regression equation, correlation coefficient and detection limit [11] determined for the method are given in Table 1 .

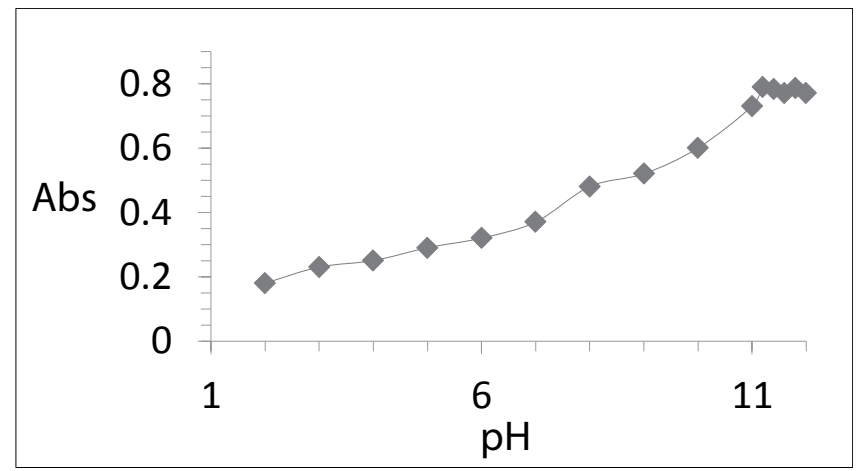

Figure 3: Effect of the pH value on absorption of CRT-AR complex.

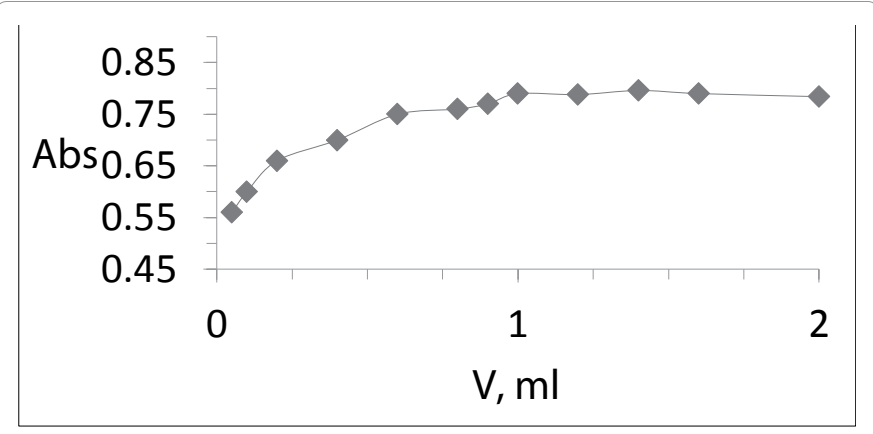

Figure 4: Effect of amount of britton( $0.1 \mathrm{M})$ buffer $(\mathrm{pH} 5.2)$.

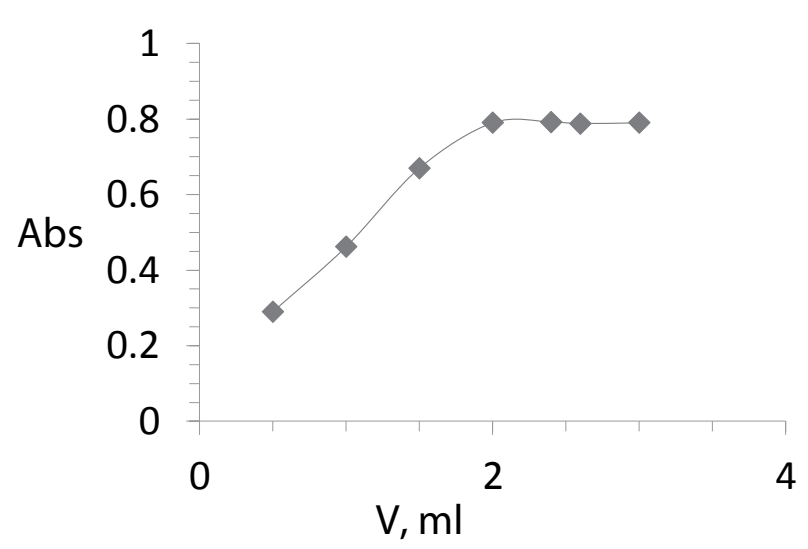

Figure 5: Effect of the amount of( AR) on on absorbance of CRT-AR complex.

\section{Accuracy and precision}

The results obtained are summarized in Table 2. The low values of relative standard deviation (RSD) indicates good precision and reproducibility of the method. The average percent recoveries obtained were $95.55-100.83 \%$, indicating good accuracy of the methods $[12,13]$.

\section{Application to the pharmaceutical dosage forms}

The proposed method has been successfully applied to the determination of CRT in pharmaceutical preparations Table 3. The ingredients in the tablets did not interfere in the experiments.

\section{Conclusion}

The proposed method for the estimation of Cartelol using Alizarin 


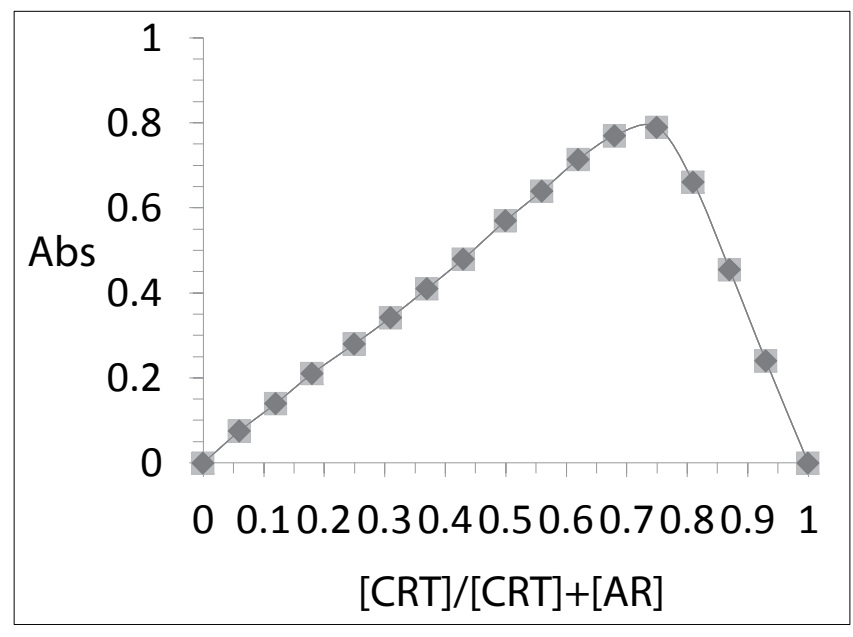

Figure 6: Continuous Variation plot for CRT-AR complex.

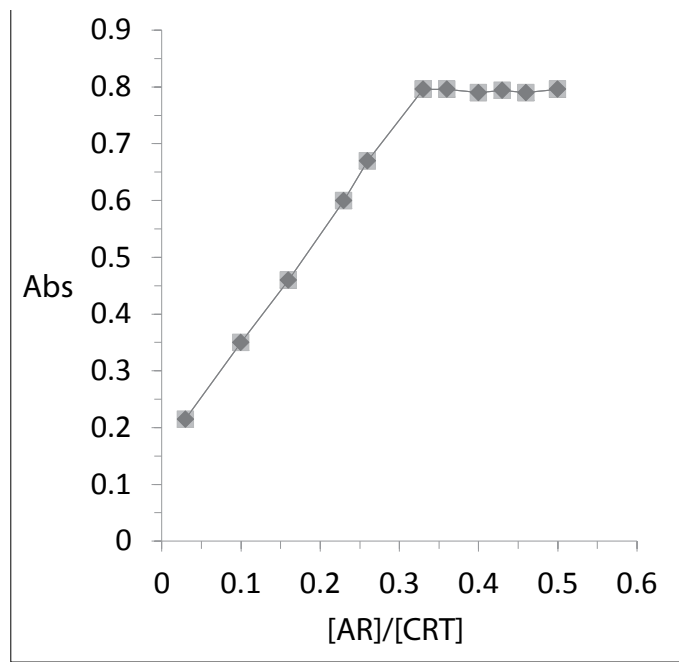

Figure 7: Molar ratio plot for CRT-AR complex.

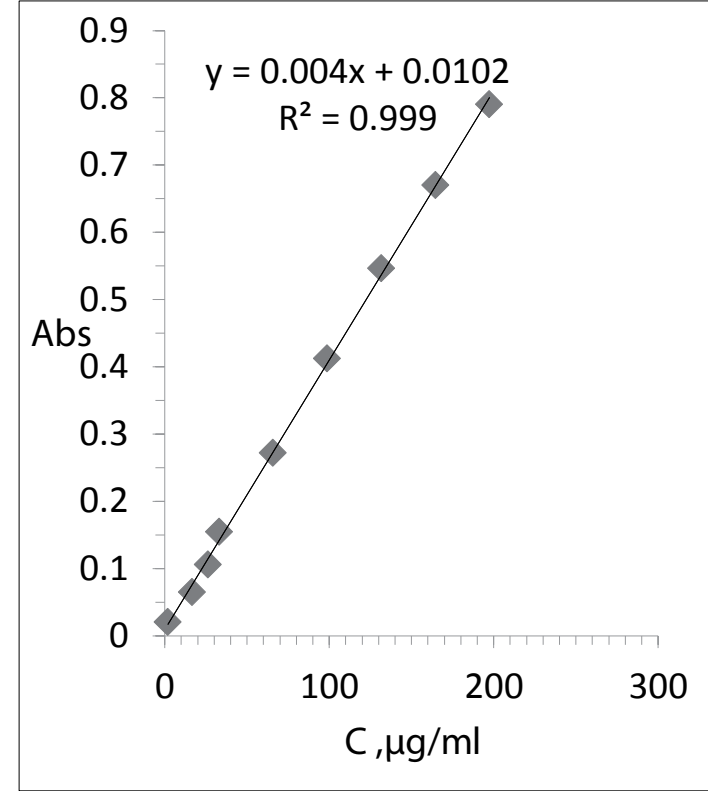

Figure 8: Calibration rang for Carteolol.

\begin{tabular}{|l|c|}
\hline Parameter & Value \\
\hline$\lambda_{\text {max }}(\mathrm{m})$ & 500 \\
\hline Beer's law limit $(\mu \mathrm{g} / \mathrm{mL})$ & $1.80-197.30$ \\
\hline Molar absorptivity $\left(\mathrm{L} \mathrm{mole}{ }^{-1} \mathrm{~cm}^{-1}\right)$ & $1.7663 \times 10^{3}$ \\
\hline Sandell's sensitivity $(\mu \mathrm{g} / \mathrm{mL}$ per0.001 $\mathrm{A})$ & 0.18 \\
\hline Slope $(\mathrm{m})$ & 0.0044 \\
\hline Intercept $(\mathrm{c})$ & 0.0102 \\
\hline Correlation coefficient & 0.999 \\
\hline Relative Standard Deviation & \\
\hline Limit of Detection $(\mu \mathrm{g} / \mathrm{mL})$ & 3.48 \\
\hline Limit of quantitation $(\mu \mathrm{g} / \mathrm{ml})$ & 0.52 \\
\hline
\end{tabular}

$\mathrm{Y}=\mathrm{mx}+\mathrm{C}$

Where $X$ is the concentration of analyte $(\mu \mathrm{g} / \mathrm{mL})$ and $Y$ is absorbance unit. * = Calculated from five determinations

Table 1: Optical characteristics and statistical data for the regression equation of the proposed method.

\begin{tabular}{|c|c|c|c|c|c|c|}
\hline CRT Taken $(\mu \mathrm{g} / \mathrm{ml})$ & $\begin{array}{l}\text { CRT Found* } \\
\qquad(\mu \mathrm{g} / \mathrm{ml})\end{array}$ & Standard Deviation SD & $\begin{array}{l}\text { Relative Standard } \\
\text { Deviation RSD \% }\end{array}$ & $\begin{array}{l}\text { analytical Error SD/ } \\
\qquad(\mathrm{n})^{1 / 2}\end{array}$ & Confidence limit $(\mu \mathrm{g} / \mathrm{ml})$ & Recovery\% R (\%) \\
\hline 1.80 & 1.72 & 0.060 & 3.48 & 0.026 & $1.80 \pm 0.072$ & 95.55 \\
\hline 16.44 & 16.08 & 0.271 & 1.68 & 0.121 & $16.08 \pm 0.335$ & 97.81 \\
\hline 26.30 & 25.8 & 0.667 & 2.58 & 0.298 & $25.8 \pm 0.827$ & 98.09 \\
\hline 32.88 & 32.75 & 0.089 & 0.27 & 0.039 & $32.75 \pm 0.108$ & 99.6 \\
\hline 65.76 & 66.31 & 0.676 & 1.01 & 0.302 & $66.31 \pm 0.838$ & 100.83 \\
\hline 98.65 & 99.43 & 1.536 & 1.54 & 0.686 & $99.43 \pm 1.904$ & 100.79 \\
\hline 131.53 & 131.96 & 0.588 & 0.44 & 0.262 & $131.96 \pm 0.727$ & 100.32 \\
\hline 164.42 & 165.26 & 1.183 & 0.71 & 0.529 & $165.26 \pm 1.468$ & 100.51 \\
\hline 197.30 & 196.36 & 1.254 & 0.63 & 0.560 & $196.36 \pm 1.554$ & 99.52 \\
\hline
\end{tabular}

*Average of five determinations.

Table 2: Study of the precision and of the accuracy of the method.

\begin{tabular}{|c|c|c|c|c|c|c|c|}
\hline Formulation & $\begin{array}{l}\text { Label claim } \\
\text { (mg) }\end{array}$ & $\begin{array}{l}\text { CRT Taken }(\mu \mathrm{g} / \\
\mathrm{ml})\end{array}$ & $\begin{array}{l}\text { CRT Found ( } \mu \mathrm{g} / \\
\mathrm{ml})\end{array}$ & $\begin{array}{c}\text { Standard } \\
\text { Deviation SD }\end{array}$ & $\begin{array}{c}\text { Content determined } \\
(\mathrm{mg})\end{array}$ & $\begin{array}{l}\text { Relative Standard } \\
\text { Deviation RSD \% }\end{array}$ & Recovery\% R (\%) \\
\hline \multirow[t]{2}{*}{ CALTE } & 100 & 50 & 49.68 & 0.474 & 99.36 & 0.95 & 99.36 \\
\hline & 10 & 100 & 99.32 & 0.506 & 99.32 & 0.51 & 99.32 \\
\hline
\end{tabular}

${ }^{*}$ Five independent analyses

Table 3: Results of the estimation of CRT in tablets. 
Citation: Okdeh M, Moustpha C, Shraitah M (2016) Determination of Carteolol in Pure and Pharmaceutical Formulation by Spectrophotometric Method. Med chem (Los Angeles) 6: 115-118. doi:10.4172/2161-0444.1000334

yellow R Sodium salt (AR) are advantageous over many of the reported methods. The methods are rapid, simple and have good sensitivity and accuracy. Proposed method makes use of simple reagent, which an ordinary analytical laboratory can afford. The high recovery percentage and low relative standard deviation reflect the high accuracy and precision of the proposed method. The method are easy, applicable to a wide range of concentration, besides being less time consuming and depend on simple reagent which are available, thus offering economic and acceptable method for the routine determination of Cartelol in its formulations.

\section{References}

1. Black CD, Mann HJ (1984) Intrinsic sympathomimetic activity: physiological reality or marketing phenomenon. Drug Intell Clin Pharm 18: 554-559.

2. Moroi SE, Lichter PR (2001) In: Hardman JG, Limbird LE, Gilman AG (Eds.), Ocular Pharmacology, in Goodman and Gilman's The Pharmacological Basis of Therapeutics, 10th ed. McGraw-Hill, New York, 1821.

3. Nathanson JA (1980) Effects of a potent and specific beta 2-adrenoceptor antagonist on intraocular pressure. PNAS USA 77: 7420-7424.

4. Kuwahara K, Oizumi N, Fujisawa S, Tanito M, Ohira A (2005) Carteolo hydrochloride protects human corneal epithelial cells from UVB-induced damage in vitro. Cornea 24: $213-220$

5. Trinquand C, Romanet JP, Nordmann JP, Allaire C; Groupe d'etude (2003)
Efficacy and safety of long-acting carteolol $1 \%$ once daily. A double-masked, randomized study. J Fr Ophtalmol 26: 131-136.

6. Zammataro A, Saletti R, Civiale C, Muccilli V, Cunsolo V, et al. (2010) Simultaneous quantification of carteolol and dorzolamide in rabbit aqueous humor and ciliary body by liquid chromatography/ atmospheric pressure chemical ionization mass spectrometry. J Chromatogr B Analyt Technol Biomed Life Sci 878: 807-814.

7. El-Kamel A, Al-Dosari H, Al-Jenoobi F (2006) Environmentally responsive ophthalmic gel formulation of carteolol hydrochloride. Drug Deliv 13: 55-59.

8. Yoe JH, Jones AL (1944) Colorimetric Determination of Iron with disodium ,2-dihydroxybenzene-3,5-disulfonate. Journal of Industrial \& Engineering Chemistry 16: 14-19.

9. Warren CV, Gerald RC (1941) Complex lons. I. The Identification of Complex ions in Solution by Spectrophotometric measurements. JACS 63: 437-442.

10. Mlller JC, Mlller JN (1993) Statistics in Analytical Chemistry; 3rd ed., Ellis Horwood, Chichester, 119.

11. Validation of Analytical Procedure Methodology (1996) $\mathrm{ICH}$ Harmonized Tripartite Guideline, Q2B, 1-8.

12. International conference on harmonization October: (1994) Text on Validation of Analytical Procedures Q 29(A).

13. Golcu A, Ozkan SA (2006) Electroanalytical determination of donepezil $\mathrm{HCl}$ in tablets and human serum by differential pulse and osteryoung square wave voltammetry at a glassy carbon electrode. Pharmazie 61: 760-765. 